\title{
PERSEPSI GURU PENDIDIKAN AGAMA ISLAM TERHADAP PEMBELAJARAN DAN KEBIJAKAN PENDIDIKAN SELAMA PANDEMI COVID-19
}

\author{
Elismarwati \\ Kementerian Agama Kabupaten Bengkulu Tengah, Bengkulu, Indonesia \\ Email: elismarwati67@gmail.com
}

\begin{abstract}
The Covid-19 pandemic has made significant changes in the education sector, especially schools. Schools throughout Indonesia during the Covid-19 pandemic did online learning. Teachers' Islamic education perceptions will affect the educational process, as well as teacher perceptions of educational policy. The purpose of this study was to determine teacher perceptions of learning and education policy during the Covid-19 pandemic. The research method used is quantitative research with a descriptive approach. The results of the study found that teachers felt dissatisfied with learning done online; online learning was not yet effective; teachers also still had difficulty implementing online learning and difficulty in mastering the teaching tools. Teachers' perceptions of education policy show good things because schools are ready in terms of policies, regulations, and ICT infrastructure in the form of the internet. The internet network at school is needed by teachers who have difficulty getting signals at home so that teachers can carry out online learning from schools while still following the health protocol.
\end{abstract}

Keywords: Teacher Perception, Learning, Education Policy, Covid-19 Pandemic

\begin{abstract}
Abstrak: Pandemi Covid-19 telah membuat perubahan besar di sektor pendidikan, terutama sekolah. Sekolah di seluruh Indonesia saat pandemi Covid-19 didorong melakukan pembelajaran secara online. Persepsi guru Pendidikan Agama Islam terhadap pembelajaran berpengaruh terhadap proses pendidikan, demikian juga halnya persepsi guru terhadap kebijakan pendidikan. Tujuan penelitian ini untuk mengetahui persepsi guru terhadap pembelajaran dan kebijakan pendidikan selama pandemi Covid-19. Metode penelitian yang digunakan adalah penelitian kuantitatif dengan pendekatan deskriptif. Hasil penelitian ditemukan bahwa guru merasa tidak puas terhadap pembelajaran yang dilakukan secara online, pembelajaran secara online belum berjalan dengan efektif, guru juga masih kesulitan dalam melaksanakan pembelajaran secara online dan kesulitan dalam menguasai alat pengajarannya. Persepsi guru terhadap kebijakan pendidikan menunjukkan hal baik, karena sekolah siap dalam hal kebijakan, peraturan serta infrastruktur TIK berupa internet. Jaringan internet yang ada disekolah sangat membantu guru yang kesulitan untuk mendapatkan sinyal di rumah, sehingga guru dapat melaksanakan pembelajaran online dari sekolah dengan tetap mengikuti protokol kesehatan.
\end{abstract}

Kata Kunci: Persepsi Guru, Pembelajaran, Kebijakan Pendidikan, Pandemi Covid-19

\section{PENDAHULUAN}

Saat artikel ini ditulis pada bulan Juni 2020, pertambahan kasus positif Covid-19 di Indonesia sebanyak 2.657 kasus yang merupakan rekor pertambahan kasus positif baru, saat ini kasus positif di Indonesia mencapai 70.736, sembuh 32.651, dan meninggal 3.417 (BNPB, 2020). Pandemi Covid-19 ini sendiri telah membuat pengaruh yang sangat besar terhadap pendidikan, salah satu akibat pandemi ialah pembelajaran yang dilakukan secara online (Daniel, 2020; Nurkholis, 2020). Hal ini demi menjaga tidak tersebarnya virus 
Covid-19 dengan menerapkan social distancing (Stein, 2020). Pembelajaran secara online sendiri merupakan pilihan paling tepat untuk diterapkan disekolah selama penerapan social distancing dan belajar dari rumah (Herliandry, Nurhasanah, Suban, \& Heru, 2020). Walaupun pembelajaran dilakukan secara online, tapi sebaiknya tidak mempengaruhi kualitas pembelajaran yang sedang berlangsung.

Guru pendidikan agama Islam menghadapi masalah tersendiri, karena karateristik pembelajaran pendidikan agama Islam, berbeda dan spesifik dibanding dengan pembelajaran yang lain. Pembelajaran pendidikan agama Islam memperhatikan perbaikan disisi sikap (afektif) tidak semata-mata hanya mementingkan aspek kognitif saja (Novayani, 2018). Persepsi guru terhadap pendidikan berpengaruh besar terhadap hasil dan capaian pendidikan (Fatimah, Siti Tamuri, 2010; Dewi, 2015).

Kebijakan pendidikan selama pandemi Covid-19 merupakan salah satu faktor pendukung berhasilnya proses belajar-mengajar, karena dukungan kebijakan pendidikan ini secara langsung memberikan motivasi terhadap guru (Bakry, 2010; Arifa, 2020). Berdasarkan beberapa hal diatas maka perlu dilakukan penelitian tentang persepsi guru terhadap pembelajaran dan kebijakan pendidikan selama pandemi Covid-19, agar ada refleksi terhadap pembelajaran yang telah berlangsung, tujuan lebih jaunya agar ada perbaikan apabila nantinya ditemukan kekurangan-kekurangan dalam praktek pembelajaran selama pandemi Covid-19.

\section{LANDASAN TEORI}

\section{Persepsi}

Persepsi merupakan pemahaman seseorang terhadap sesuatu sesuai dengan rangsangan yang ditangkap oleh indera orang tersebut (Rofi'ah, 2017). Pengertian lain menurut Walgito, persepsi adalah suatu kesan terhadap suatu obyek yang diperoleh melalui proses penginderaan, pengorganisasian, dan interpretasi terhadap obyek tersebut yang diterima oleh individu, sehingga merupakan suatu yang berarti dan merupakan aktivitas integrated dalam diri individu (Walgito, 2010). Berdasarkan pengertian diatas, maka persepsi guru dapat diartikan sebagai pemahaman atau kesan guru terhadap pembelajaran. Persepsi guru terhadap pembelajaran akan mempengaruhi proses belajar. Sutrisno menyebutkan bahwa persepsi guru terhadap pembelajaran sangat mempengaruhi proses dan hasil belajar (Sutrisno \& Siswanto, 2016). Maka persepsi guru yang baik akan menyebabkan proses pembelajaran yang baik pula. 


\section{Pembelajaran Pendidikan Agama Islam}

Pembelajaran PAI merupakan pembelajaran mengutamakan pendidikan keimanan, untuk menghasilkan lulusan yang baik akhlaknya dalam kehidupan berbangsa dan bernegara (Rochidin, 2011). Pendidikan agama Islam sebaiknya diajarkan pada siswa melalui pembinaan sikap (afektif), keterampilan (psikomotor), dan pengetahuan (kognitif), juga konatif dan performance (Rochidin, 2011). Pada masa pandemi Covid19 seperti saat ini, pembelajaran hanya dititik beratkan pada aspek kognitif saja, sehingga aspek afektif kurang tersentuh diakibatkan kurangnya interaksi antara guru dan siswa.

\section{Kebijakan Pendidikan}

Kebijakan pendidikan merupakan rumusan dari berbagai cara untuk mewujudkan tujuan pendidikan nasional, diwujudkan atau dicapai melalui lembagalembaga sosial (social institutions) atau organisasi sosial dalam bentuk lembagalembaga pendidikan formal, nonformal, dan informal (Solichin, 2015). Kebijakan yang diterapkan di lembaga lembaga pendidikan (pemerintah) dalam mendukung dan menghargai profesi guru dalam bentuk pembiayaan atau gaji yang sesuai, menyediakan sarana dan prasaran pendukung kegiatan belajar mengajaran, mengatasi kelas yang padat, dan peningkatan profesionalisme guru dalam bentuk pelatihan atau sejenisnya (Pingge, 2016). Maka dari itu diperlukan kebijakan pendidikan yang mendukung guru selama pandemi Covid-19, agar hasil belajar yang baik dapat tercapai.

\section{METODE PENELITIAN}

Metode penelitian yang digunakan merupakan metode kuantitatif dengan pendekatan deskriptif. Metode kuantitatif merupakan penelitian yang data penelitiannya berupa angka-angka dan analisis menggunakan statistik (Sugiyono, 2016). Tujuan dari penelitian deskriptif yaitu untuk membuat deskripsi, gambaran, atau lukisan secara sistematis, faktual dan akurat mengenai fakta-fakta, sifat-sifat serta hubungan antar fenomena yang diselidiki (Gumanti, Yudiar, \& Syahruddin, 2016). Pengumpulan data dilakukan selama bulan Juli 2020, dengan melibatkan 57 guru PAI yang berasal dari 36 sekolah SD, SLB, SMA, dan SMK di Kabupaten Bengkulu Tengah. Data lengkap nama sekolah dan jumlah guru PAI yang menjadi sampel dan sumber data dapat dilihat pada Tabel 1. 
Tabel 1. Data sekolah dan jumlah guru PAI

\begin{tabular}{|c|c|c|}
\hline $\mathrm{NO}$ & Nama Sekolah & Jumlah guru PAI \\
\hline 1. & SD N 01 Bengkulu Tengah & 3 \\
\hline 2. & SD N 02 Bengkulu Tengah & 3 \\
\hline 3. & SD N 05 Bengkulu Tengah & 2 \\
\hline 4. & SD N 06 Bengkulu Tengah & 1 \\
\hline 5. & SD N 07 Bengkulu Tengah & 2 \\
\hline 6. & SD N 11 Bengkulu Tengah & 2 \\
\hline 7. & SD N 13 Bengkulu Tengah & 1 \\
\hline 8. & SD N 15 Bengkulu Tengah & 1 \\
\hline 9. & SD N 18 Bengkulu Tengah & 2 \\
\hline 10. & SD N 26 Bengkulu Tengah & 1 \\
\hline 11. & SD N 27 Bengkulu Tengah & 1 \\
\hline 12. & SD N 31 Bengkulu Tengah & 1 \\
\hline 13. & SD N 35 Bengkulu Tengah & 1 \\
\hline 14. & SD N 37 Bengkulu Tengah & 1 \\
\hline 15. & SD N 41 Bengkulu Tengah & 1 \\
\hline 16. & SD N 53 Bengkulu Tengah & 1 \\
\hline 17. & SD N 54 Bengkulu Tengah & 1 \\
\hline 18. & SD N 59 Bengkulu Tengah & 1 \\
\hline 19. & SD N 62 Bengkulu Tengah & 1 \\
\hline 20. & SD N 68 Bengkulu Tengah & 2 \\
\hline 21. & SD N 69 Bengkulu Tengah & 1 \\
\hline 22. & SD N 73 Bengkulu Tengah & 1 \\
\hline 23. & SD N 75 Bengkulu Tengah & 1 \\
\hline 24. & SD N 76 Bengkulu Tengah & 1 \\
\hline 25. & SD N 79 Bengkulu Tengah & 1 \\
\hline 26. & SD N 80 Bengkulu Tengah & 2 \\
\hline 27. & SD N 81 Bengkulu Tengah & 1 \\
\hline 28. & SD N 82 Bengkulu Tengah & 1 \\
\hline 29. & SD N 88 Bengkulu Tengah & 2 \\
\hline 30. & SD N 89 Bengkulu Tengah & 1 \\
\hline 31. & SDIT Al-Ikhsan Bengkulu Tengah & 1 \\
\hline 32. & SLB N 1 Bengkulu Tengah & 1 \\
\hline 33. & SMA N 1 Bengkulu Tengah & 4 \\
\hline 34. & SMA N 3 Bengkulu Tengah & 4 \\
\hline 35. & SMA N 6 Bengkulu Tengah & 2 \\
\hline 36. & SMK N 2 Bengkulu Tengah & 4 \\
\hline \multicolumn{2}{|r|}{ Jumlah } & 57 \\
\hline
\end{tabular}


Data dikumpulkan dengan bantuan google form, hal ini dengan pertimbangan untuk mengikuti aturan pemerintah untuk menerapkan social distancing. Instrumen penelitian diadaptasi dari pengumpulan data perspektif yang dilakukan oleh $\mathrm{Vu}$ di Vietnam yang mengumpulkan data perspektif guru (Vu et al., 2020).

\section{HASIL DAN PEMBAHASAN}

\section{Data Demografi Responden}

Guru yang menjadi sumber data memiliki 3 jenis latar pendidikan, yaitu : 1 guru pendidikan terakhirnya SMA, 50 guru pendidikan Sarjana (S1), 6 guru sudah mengenyam pendidikan sampai Master (S2), sedangkan yang bergelar doktor belum ada. Dari data ini dapat terlihat bahwa masih ada guru yang secara pendidikan belum layak untuk mengajar di sekolah, karena minimal pendidikan guru harusnya adalah S1. Untuk jenis kelamin, guru perempuan lebih banyak daripada guru laki-laki, yaitu 39 perempuan dan 18 lakilaki. Untuk data pengalaman mengajar, ditemukan bahwa guru yang memiliki pengalaman mengajar lebih dari 10 tahun sebanyak 32 guru atau 56,1\%, ini menandakan bahwa guru sudah sangat berpengalaman di dalam mengajar. 15 guru atau 26,3\% sudah mengajar antara 5-10 tahun, 2 atau 3,5\% guru dengan pengalaman, antara 3-5 tahun, dan masih ada 8 guru atau $14 \%$ yang memiliki pengalaman mengajar dibawah 3 tahun.

Untuk melengkapi data demografi, guru diberikan pertanyaan apakah pandemi Covid-19 mempengaruhi rencana keuangan, 27 guru atau 47,4\% menjawab bahwa pandemi Covid-19 mengganggu rencana keuangan mereka, 25 guru atau 45,6\% menajawab tidak, sedangkan sisanya 4 guru atau $7 \%$ menjawab ragu-ragu. Data selanjutnya mengenai penghasilan guru sebelum dan selama pandemi Covid-19, serta harapan guru terhadap penghasilan setelah pandemi Covid-19. Data yang terkumpul menunjukkan rata-rata penghasilan guru selama pandemi Covid-19 menurun bila dibandingkan dengan sebelum pandemi Covid-19, yaitu rata-rata Rp. 3.435.368 sebelum pandemi Covid-19 dan rata-rata Rp. 3.387.017 selama pandemi Covid-19, dengan penurunan rata-rata sebesar Rp. 48.351. Penyebab menurunnya penghasilan guru ini adalah berkurangnya penghasilan guru di luar gaji yang didapatkan dari sekolah. Salah satu penghasilan guru sebelum pandemi Covid-19 adalah mengajar les dan berdagang, selama pandemi Covid-19 kegiatan les dan berdagang yang dilakukan oleh guru berhenti. Untuk harapan penghasilan setelah pandemi Covid-19, hampir seluruh guru 
mengharapkan kenaikan penghasilan setelah pandemi berakhir. Harapan ini bisa saja disebabkan karena selama pandemi Covid-19 penghasilan guru menurun.

Untuk data lebih lengkap tentang demografi Guru pendidikan agama Islam bisa dilihat pada Tabel 2.

Tabel 2. Data demografi guru PAI

\begin{tabular}{|c|c|c|c|}
\hline Pertanyaan & Jawaban & Jumlah & $\%$ \\
\hline \multirow[t]{4}{*}{ Pendidikan Terakhir } & SMA & 1 & $1,8 \%$ \\
\hline & S1 Sarjana & 50 & $87,7 \%$ \\
\hline & S2 Master & 6 & $10,5 \%$ \\
\hline & S3 Doktor & - & - \\
\hline \multirow[t]{2}{*}{ Jenis Kelamin } & Laki-laki & 18 & $31,6 \%$ \\
\hline & Perempuan & 39 & $68,4 \%$ \\
\hline \multirow[t]{4}{*}{ Pengalaman Mengajar } & Kurang dari 3 tahun & 8 & $14 \%$ \\
\hline & Antara 3-5 tahun & 2 & $3,5 \%$ \\
\hline & Antara 5-10 tahun & 15 & $26,3 \%$ \\
\hline & Lebih dari 10 tahun & 32 & $56,1 \%$ \\
\hline \multirow{3}{*}{$\begin{array}{l}\text { COVID-19 mengancam rencana } \\
\text { keuangan Anda? }\end{array}$} & $\mathrm{Ya}$ & 27 & $47,4 \%$ \\
\hline & Tidak & 25 & $45,6 \%$ \\
\hline & Ragu-ragu & 4 & $7 \%$ \\
\hline $\begin{array}{l}\text { Berapa Penghasilan bulanan Anda } \\
\text { sebelum COVID-19? (dalam juta) }\end{array}$ & Rata-rata & $\begin{array}{c}3.435 .368 \\
\text { (rupiah) }\end{array}$ & \\
\hline $\begin{array}{l}\text { Berapa Penghasilan bulanan Anda } \\
\text { selama COVID-19? (dalam juta) }\end{array}$ & Rata-rata & $\begin{array}{l}3.387 .017 \\
\text { (rupiah) }\end{array}$ & \\
\hline $\begin{array}{l}\text { Berapa penghasilan yang diharapkan } \\
\text { setelah COVID-19? (dalam juta ) }\end{array}$ & Rata-rata & $\begin{array}{l}4.885 .964 \\
\text { (rupiah) }\end{array}$ & \\
\hline
\end{tabular}

\section{Pengaruh Pandemi Covid-19 Terhadap Kesehatan}

Pada pertanyaan apakah pandemi Covid-19 mempengaruhi kesehatan, ternyata mayoritas guru sebanyak 46 orang atau $80,7 \%$ menjawab tidak, ternyata secara keseluruhan bisa dikatakan pandemi Covid-19 tidak mempengaruhi kesehatan guru PAI di Bengkulu Tengah. Pertanyaan selanjutnya adalah apakah pandemi Covid-19 mempengaruhi kebiasaan sehari-hari dan membuat lelah, ternyata kebanyakan guru menjawab tidak, sebanyak 34 guru atau 59, 6\%. Hal ini menunjukkan bahwa pandemi 
Jurnal As-Salam Vol. 4 No. 2 Juli - Desember 2020: 231 - 245

Elismarwati

Covid-19 tidak begitu mengganggu bagi guru. Untuk lebih lengkap data pengaruh pandemi Covid-19 terhadap kesehatan, dapat dilihat pada Tabel 3.

Tabel 3. Pengaruh pandemi Covid-19 terhadap kesehatan

\begin{tabular}{l|l|c|c}
\hline \multicolumn{1}{c|}{ Pertanyaan } & \multicolumn{1}{|c|}{ Jawaban } & Jumlah & \% \\
\hline Secara keseluruhan, COVID-19 & Ya & 7 & $12,3 \%$ \\
\cline { 2 - 4 } \begin{tabular}{l} 
mempengaruhi kesehatan Anda? \\
\cline { 2 - 4 }
\end{tabular} & Tidak & 46 & $80,7 \%$ \\
\cline { 2 - 4 } & Ragu-ragu & 4 & $7 \%$ \\
\hline COVID-19 mengubah kebiasaan & Ya & 19 & $33,4 \%$ \\
\cline { 2 - 4 } $\begin{array}{l}\text { sehari-hari Anda dan membuat Anda } \\
\text { lelah? }\end{array}$ & Tidak & 34 & $59,6 \%$ \\
\cline { 2 - 4 } & Ragu-ragu & 4 & $7 \%$ \\
\hline
\end{tabular}

\section{Dukungan Terhadap Guru Selama Pandemi Covid-19}

Survei juga dilakukan terhadap dukungan pada guru selama pandemi Covid-19, untuk melihat apakah guru mendapat dukungan dari sekolah dan pemerintah, khususnya dukungan dalam hal pelaksanaan pembelajaran yang dilakukan secara online. Data yang dihimpun menunjukkan bahwa guru sebanyak 48 orang atau 84,2\% mengatakan mendapat dukungan dari sekolah, 4 guru atau 7\% mengatakan tidak mendapat dukungan, serta 5 guru atau 8,8\% menjawab ragu-ragu. Hal yang perlu diperhatikan adalah pada jawaban tidak dan ragu-ragu, ini menunjukkan bahwa masih ada sekolah yang tidak terlalu memperhatikan guru selama pandemi Covid-19, padahal untuk menjamin terlaksananya pendidikan, gurulah yang menjadi ujung tombaknya, bahkan guru jugalah penentu terlaksananya pembelajaran dengan baik. Untuk dukungan sekolah terhadap guru berupa: pembagian masker, pembagian face shield, pembagian pulsa/kuota, dan buku pelajaran. Dukungan ini sendiri pada prakteknya tidak seluruh sekolah memberikannya.

Dukungan dari pemerintah terhadap guru dapat disimpulkan baik, hal ini dapat dilihat dari data yang menunjukkan bahwa 39 atau 68,4\% guru menjawab mendapat dukungan dari pemerintah, sementara itu 11 guru atau 19,3\% menjawab tidak mendapat dukungan, serta 7 guru atau 12,3\% menjawab ragu-ragu. Walaupun dalam jawaban ini menunjukkan guru banyak yang mendapat dukungan pemerintah, tapi sebaiknya dukungan pemerintah harusnya dirasakan oleh seluruh guru. Dukungan pemerintah terhadap guru berupa pembagian bantuan sosial tunai dan bantuan sembako, tetapi tidak semua guru mendapatkan bantuan ini, hanya guru yang masuk kriteria penerima bantuanlah yang mendapatkannya. 
Untuk melengkapi data, guru juga diberikan pertanyaan berlawanan, apakah mereka tidak mendapat dukungan, apabila melihat jawaban hanya 8 guru yang menjawab ya, dan 11 guru menjawab ragu-ragu, jawaban dari pertanyaan ini singkron dengan jawaban-jawaban sebelumnya. Untuk data lebih lengkap dapat dilihat pada Tabel 4.

Tabel 4. Dukungan pada guru

\begin{tabular}{c|l|c|c}
\hline \multicolumn{1}{c|}{ Pertanyaan } & \multicolumn{1}{|c|}{ Jawaban } & Jumlah & $\%$ \\
\hline \multirow{2}{*}{$\begin{array}{l}\text { Selama COVID-19, Anda menerima } \\
\text { dukungan dari sekolah? }\end{array}$} & Ya & 48 & $84,2 \%$ \\
\cline { 2 - 4 } & Tidak & 4 & $7 \%$ \\
\cline { 2 - 4 } & Ragu-ragu & 5 & $8,8 \%$ \\
\hline \multirow{2}{*}{$\begin{array}{l}\text { Selama COVID-19, Anda menerima } \\
\text { dukungan dari pemerintah? }\end{array}$} & Ya & 39 & $68,4 \%$ \\
\cline { 2 - 4 } & Tidak & 11 & $19,3 \%$ \\
\cline { 2 - 4 } & Ragu-ragu & 7 & $12,3 \%$ \\
\hline $\begin{array}{l}\text { Selama COVID-19, Anda tidak } \\
\text { menerima dukungan apa pun? }\end{array}$ & Ya & 38 & $66,7 \%$ \\
\cline { 2 - 4 } & Tidak & 11 & $19,3 \%$ \\
\cline { 2 - 4 } & Ragu-ragu & & $14 \%$ \\
\hline
\end{tabular}

\section{Persepsi Guru Terhadap Pembelajaran}

Data persepsi guru yang pertama adalah mengenai penguasaan guru terhadap alat pengajaran online yang digunakan selama mengajar dari rumah, data yang terkumpul ternyata guru yang menguasai alat pembelajaran secara online hanya 24 guru atau $42,1 \%$, yang menjawab tidak menguasai ada 11 guru atau 19,3\%, sedangkan sisanya menjawab ragu-ragu sebanyak 22 guru atau 38,6\%. Hal ini menunjukkan bahwa lebih dari setengah guru masih belum menguasai alat pengajaran online, hal ini dikhawatirkan akan berdampak terhadap kurang maksimalnya proses pembelajaran yang berlangsung. Studi membuktikan bahwa pemanfaatan media pembelajaran audio-visual dapat meningkatkan pengetahuan dan sikap (Ulfa, Stang, Tahir, Mallongi, \& Rachmat, 2020).

Persepsi selanjutnya adalah mengenai apakah guru tidak menghadapi kesulitan saat melakukan pengajaran secara online, ternyata 28 guru atau 49,1\% menjawab tidak menghadapi kesulitan. Sementara itu 17 guru menjawab menghadapi kesulitan dan 12 guru menjawab ragu-ragu. Apabila digabungkan jawaban antara menghadapi kesulitan 
dengan ragu-ragu, maka persentasenya lebih besar dari pada menjawab tidak kesulitan. Hal ini harus diperhatikan karena gabungan besaran jawaban antara keduanya sebesar 50, 9\% atau lebih banyak dari pada yang menjawab tidak mengahadapi kesulitan. Apabila fakta seperti ini yang ditemukan, bisa saja ternyata guru memang kebanyakan mengahadapi kesulitan saat melakukan pembelajaran secara online. Pembelajaran menggunakan teknologi harus berhati-hati dalam penggunaannya, agar menunjukkan hasil yang maksimal (Bayne, 2015).

Untuk menilai keefektifan pembelajaran selama kelas online berjalan, guru diberikan pertanyaan apakah pembelajaran online sama efektifnya dengan pembelajaran yang dilakukan secara normal, data yang terkumpul guru sebanyak 35 orang atau $61,4 \%$ menjawab tidak, 17 guru menjawab efektif, sedangkan sisanya 5 guru menjawab raguragu. Hal ini dapat mencerminkan bahwa ternyata guru merasa bahwa pembelajaran online sebenarnya kurang efektif.

Untuk pertanyaan tentang keaktifan siswa saat pembelajaran online, terlihat bahwa hanya 25 guru atau 43,9\% guru yang menjawab aktif, sisanya 21 guru menjawab tidak dan 11 guru menjawab ragu-ragu. Dari data ini terlihat bahwa sebagian besar siswa ternyata tidak aktif dalam pembelajaran yang dilakukan secara online. Untuk pertanyaan apakah guru merasa bahwa beban kerja bertambah selama pandemi Covid-19, ternyata hanya 23 guru atau 40,4\% yang menjawab ya, 25 atau 43,9\% guru menjawab tidak, dan 9 guru atau 15,8\% menjawab ragu-ragu. Dari data ini dapat disimpulkan bahwa mayoritas guru sebenarnya tidak merasa bahwa belajar secara online terlalu membebani.

Untuk pertanyaan mengenai meningkatnya kompetensi, guru diberikan beberapa pertanyaan, yaitu: (1) Saya tahu banyak jenis platform TIK, alat, dan aplikasi untuk mengajar online; (2) Selama Covid-19, saya telah belajar banyak pengetahuan dan keterampilan TIK baru; dan (3) Selama Covid-19, saya telah belajar banyak pengetahuan dan keterampilan pedagogis baru. Dapat disimpulkan bahwa pembelajaran secara online ini telah meningkatkan banyak kemampuan dan pemahaman guru dalam pembelajaran online, begitu juga kemampuan guru dalam pedagogisnya sudah bertambah. Bertambahnya kemampuan TIK merupakan suatu kemajuan yang baik bagi dunia pendidikan (Pujilestari, 2020).

Untuk melihat apakah guru merasa stres saat melakukan pembelajaran secara online, maka guru juga diberikan pertanyaan, saya merasa stres karena pengajaran online. Hasilnya 19 guru menjawab ya, artinya ada 33,3\% guru yang merasa stress saat 
melakukan pembelajaran secara online, sementara itu 27 guru menjawab tidak, dan sisanya 11 guru menjawab ragu-ragu. Dari data ini terlihat sebenarnya kebanyakan guru tidak merasa stres melakukan pembelajaran secara online, tapi hal yang harus menjadi perhatian adalah adanya guru yang merasa stres saat melaksanakan pembelajaran online. Guru yang merasa stres saat pembelajaran online inilah yang perlu menjadi perhatian, disinilah diperlukan bantuan dari berbagai pihak untuk membantu guru mengatasi masalah yang dihadapi selama melakukan pembelajaran secara online.

Guru juga diberikan 2 pertanyaan tentang dukungan yang mereka dapatkan selama melakukan pembelajaran secara online. Pertanyaan yang diberikan yaitu: (1) Sebagian besar pengetahuan dan keterampilan baru saya adalah karena dukungan sekolah saya; dan (2) Sebagian besar pengetahuan dan keterampilan baru saya adalah karena dukungan dari rekan-rekan saya. Dari jawaban yang diberikan oleh guru, mayoritas terlihat bahwa guru mendapatkan dukungan dari sekolah dan rekan-rekannya.

Pertanyaan terakhir tentang persepsi adalah apakah guru puas dengan pembelajaran secara online, ternyata hanya 21 guru atau $37 \%$ yang menjawab ya, sedangkan 24 guru atau $42 \%$ menjawab tidak, sisanya menjawab ragu-ragu sebanyak 12 guru atau $21 \%$. Hal ini menunjukkan bahwa mayoritas guru merasa tidak puas terhadap pembelajaran yang dilakukan secara online. Oleh karena itu permasalahan ini harus secepatnya dicarikan jalan keluar, agar proses belajar dapat kembali berjalan dengan baik. Data lengkap mengenai Persepsi guru terhadap pembelajaran selama pandemi Covid-19 dapat dilihat pada tabel 5 .

Tabel 5. Persepsi guru terhadap pembelajaran

\begin{tabular}{|c|c|c|c|}
\hline Pertanyaan & Jawaban & Jumlah & $\%$ \\
\hline \multirow{3}{*}{$\begin{array}{l}\text { Saya menguasai alat pengajaran online } \\
\text { sejak sebelum COVID-19 }\end{array}$} & $\mathrm{Ya}$ & 24 & 42,1 \\
\hline & Tidak & 11 & 19,3 \\
\hline & Ragu-ragu & 22 & 38,6 \\
\hline \multirow{3}{*}{$\begin{array}{l}\text { Saya tidak menghadapi kesulitan } \\
\text { dalam pengajaran online selama } \\
\text { COVID-19 }\end{array}$} & $\mathrm{Ya}$ & 28 & 49,1 \\
\hline & Tidak & 17 & 29,8 \\
\hline & Ragu-ragu & 12 & 21,1 \\
\hline Saya tahu banyak jenis platform TIK, & Ya & 30 & 52,6 \\
\hline
\end{tabular}


Jurnal As-Salam Vol. 4 No. 2 Juli - Desember 2020: 231 - 245

Elismarwati

\begin{tabular}{|c|c|c|c|}
\hline \multirow{2}{*}{$\begin{array}{l}\text { alat, dan aplikasi untuk mengajar } \\
\text { online }\end{array}$} & Tidak & 18 & 31,6 \\
\hline & Ragu-ragu & 9 & 15,8 \\
\hline \multirow{3}{*}{$\begin{array}{l}\text { Saya merasa bahwa pengajaran online } \\
\text { sama efektifnya dengan kelas normal }\end{array}$} & $\mathrm{Ya}$ & 17 & 29,8 \\
\hline & Tidak & 35 & 61,4 \\
\hline & Ragu-ragu & 5 & 8,8 \\
\hline \multirow{3}{*}{$\begin{array}{l}\text { Saya merasa bahwa siswa aktif terlibat } \\
\text { dengan sesi online }\end{array}$} & $\mathrm{Ya}$ & 25 & 43,9 \\
\hline & Tidak & 21 & 36,8 \\
\hline & Ragu-ragu & 11 & 19,3 \\
\hline \multirow{3}{*}{$\begin{array}{l}\text { Saya merasa bahwa beban kerja } \\
\text { mengajar jauh lebih banyak daripada } \\
\text { sebelum COVID-19 }\end{array}$} & $\mathrm{Ya}$ & 23 & 40,4 \\
\hline & Tidak & 25 & 43,9 \\
\hline & Ragu-ragu & 9 & 15,8 \\
\hline \multirow{3}{*}{$\begin{array}{l}\text { Saya merasa stres karena pengajaran } \\
\text { online }\end{array}$} & $\mathrm{Ya}$ & 19 & 33,3 \\
\hline & Tidak & 27 & 47,4 \\
\hline & Ragu-ragu & 11 & 19,3 \\
\hline \multirow{3}{*}{$\begin{array}{l}\text { Selama COVID-19, saya telah belajar } \\
\text { banyak pengetahuan dan keterampilan } \\
\text { TIK baru }\end{array}$} & $\mathrm{Ya}$ & 40 & 70,2 \\
\hline & Tidak & 10 & 17,5 \\
\hline & Ragu-ragu & 7 & 12,3 \\
\hline \multirow{3}{*}{$\begin{array}{l}\text { Selama COVID-19, saya telah belajar } \\
\text { banyak pengetahuan dan keterampilan } \\
\text { pedagogis baru }\end{array}$} & $\mathrm{Ya}$ & 37 & 65 \\
\hline & Tidak & 10 & 17,5 \\
\hline & Ragu-ragu & 10 & 17,5 \\
\hline \multirow{3}{*}{$\begin{array}{l}\text { Sebagian besar pengetahuan dan } \\
\text { keterampilan baru saya adalah karena } \\
\text { dukungan sekolah saya }\end{array}$} & $\mathrm{Ya}$ & 43 & 75,5 \\
\hline & Tidak & 4 & 7 \\
\hline & Ragu-ragu & 10 & 17,5 \\
\hline \multirow{2}{*}{$\begin{array}{l}\text { Sebagian besar pengetahuan dan } \\
\text { keterampilan baru saya adalah karena }\end{array}$} & $\mathrm{Ya}$ & 47 & 82,5 \\
\hline & Tidak & 6 & 10,5 \\
\hline
\end{tabular}




\begin{tabular}{l|l|c|c}
\hline dukungan dari rekan-rekan saya & Ragu-ragu & 4 & 7 \\
\hline $\begin{array}{l}\text { Saya puas dengan pengajaran dan } \\
\text { pembelajaran online }\end{array}$ & Ya & 21 & 37 \\
\cline { 2 - 4 } & Tidak & 24 & 42 \\
\cline { 2 - 4 } & Ragu-ragu & 12 & 21 \\
\hline
\end{tabular}

\section{Persepsi Guru Terhadap Kebijakan Sekolah}

Infrastuktur TIK dalam bentuk penyediaan jaringan internet di sekolah merupakan salah satu bentuk kesiapan sekolah bertrasnformasi selama pandemi Covid-19, hal ini diperlukan karena tidak semua guru mendapatkan sinyal yang bagus untuk melaksanakan pembelajaran online dari rumah. Jadi ada guru yang harus melakukan pembelajaran online dari sekolah, selama disekolah guru tetap diwajibkan untuk mengikuti protokol kesehatan. Persepsi guru terhadap kebijakan sekolah menunjukkan jawaban yang baik, terlihat dari pertanyaan tentang kesiapan infrastuktur TIK di sekolah siap untuk transformasi selama Covid-19, sebanyak 31 guru atau 54,4\% menjawab siap, 17 guru menjawab tidak, sedangkan sisanya 9 guru menjawab ragu-ragu. Walaupun dari jawaban tersebut lebih dari setengah guru menjawab siap, tetapi persentase yang menjawab tidak dan ragu-ragu masih sangat besar, oleh karena itu sekolah baiknya memperbaiki kesiapan mereka dalam transformasi selama pandemi Covid-19. Fasilitas sekolah yang kurang baik akan menjadi penghalang potensial terhadap program-program di sekolah (Fernandes \& Sturm, 2010).

Kebijakan dan peraturan sekolah selama pandemi juga harus bertransformasi, kebijakan dan peraturan yang dilakukan oleh sekolah selama pandemi Covid-19 adalah tidak mewajibkan guru untuk melakukan absensi finger print di sekolah, melakukan pembelajaran secara online, tidak melaksanakan kegiatan yang sifatnya mengumpulkan massa, serta melakukan rapat secara daring, hal ini guna mencegah menyebarnya virus Covid-19. Persepsi guru terhadap kebijakan dan peraturan sekolah selama pandemi Covid-19, menunjukkan bahwa 37 guru atau 65\% menjawab bahwa kebijakan dan peraturan sekolah siap untuk bertransformasi selama pandemi Covid-19. Sementara itu yang menjawab tidak siap sebanyak 10 guru atau 17,5\%, dan menjawab ragu-ragu sebanyak 10 guru atau 17,5\%. Walaupun jumlah jawaban positif sangat tinggi, tapi perlu perbaikan agar kebijakan dan peraturan yang ada diseluruh sekolah siap dalam menghadapi pandemi Covid-19. Kebijakan sekolah harus mendukung guru secara penuh, 
karena kebijakan pendidikan mempengaruhi guru dalam mengajar, peran guru sangat strategis dalam melaksanakn fungsi dan tujuan pendidikan (Disas, 2017). Kebijakan pendidikan juga akan mempengaruhi kualitas pengajaran (Haruthaitlianasan, 2020). Lebih lengkap mengenai persepsi guru terhadap kebijakan sekolah dapat dilihat pada tabel 6.

Tabel 6. Persepsi guru terhadap kebijakan sekolah

\begin{tabular}{|c|c|c|c|}
\hline Pertanyaan & Jawaban & Jumlah & $\%$ \\
\hline \multirow{3}{*}{$\begin{array}{l}\text { Infrastruktur TIK sekolah saya siap } \\
\text { untuk transformasi selama COVID-19 }\end{array}$} & $\mathrm{Ya}$ & 31 & 54,4 \\
\hline & Tidak & 17 & 29,8 \\
\hline & Ragu-ragu & 9 & 15,8 \\
\hline \multirow{3}{*}{$\begin{array}{l}\text { Kebijakan dan peraturan sekolah saya } \\
\text { siap untuk transformasi selama } \\
\text { COVID-19 }\end{array}$} & $\mathrm{Ya}$ & 37 & 65 \\
\hline & Tidak & 10 & 17,5 \\
\hline & Ragu-ragu & 10 & 17,5 \\
\hline
\end{tabular}

\section{KESIMPULAN}

Persepsi guru terhadap pembelajaran selama pandemi Covid-19 menunjukkan beberapa hal, yaitu (1) guru masih kesulitan dalam melaksanakan pembelajaran secara online, hal ini bisa saja disebabkan karena belum semua guru menguasai alat pengajaran secara online; (2) guru merasa bahwa pembelajaran secara online belum efektif, serta tidak puas terhadap pembelajaran secara online; (3) guru mendapatkan pengetahuan dan keterampilan baru berkat dukungan dari sekolah dan rekan; dan (4) kemampuan guru meningkat saat mengajar menggunakan TIK; dan (5) meningkatnya kemampuan pedagosis guru.

Persepsi guru terhadap kebijakan pendidikan dalam hal ini berupa kebijakan sekolah, menunjukkan bahwa guru memiliki persepsi yang baik terhadap kebijakan sekolah, karena guru merasa bahwa infrastuktur TIK disekolah dan kebijakan serta peraturan sekolah siap untuk menghadapi pandemi Covid-19. Adapun kebijakan sekolah dalam hal TIK, berupa penyediaan fasilitas internet disekolah, hal ini diperlukan karena tidak semua guru mendapatkan sinyal internet yang baik dirumah, sehingga guru melakukan pembelajaran online disekolah dengan tetap mematuhi protokol kesehatan. Kebijakan dan peraturan sekolah selama pandemi Covid-19 berupa: tidak wajib 
melakukan absensi finger print, melakukan rapat secara daring, serta tidak melaksanakan kegiatan yang sifatnya mengumpulkan massa.

\section{DAFTAR PUSTAKA}

Arifa, F. N. (2020). Tantangan Pelaksanaan Kebijakan Belajar Dari Rumah Dalam Masa Darurat Covid-19. Info Singkat: Kajian Singkat Terhadap Isu Aktual Dan Strategis, 7(7), 13-18.

http://berkas.dpr.go.id/puslit/files/info_singkat/Info\%20Singkat-XII-7-I-P3DIApril-2020-1953.pdf

Bakry, A. (2010). Kebijakan Pendidikan sebagai Kebijakan Publik. Jurnal MEDTEK, 2(1), 1-13.

https://www.academia.edu/11348711/SEBAGAI_KEBIJAKAN_PUBLIK

Bayne, S. (2015). What's the Matter with 'Technology-Enhanced Learning'? Learning, Media and Technology, 40(1), 5-20.

https://doi.org/10.1080/17439884.2014.915851

BNPB. (2020). Virus Corona COVID-19. Retrieved from https://www.covid19.go.id/. Diakses 22 Juli 2020.

Daniel, S. J. (2020). Education and The COVID-19 Pandemic. PROSPECTS, 49, 91-96 (2020).

https://doi.org/10.1007/s11125-020-09464-3

Dewi, T. A. (2015). Pengaruh Profesionalisme Guru Dan Motivasi Kerja Terhadap Kinerja Guru Ekonomi Sma Se-Kota Malang. PROMOSI (Jurnal Pendidikan Ekonomi), 6(1), 39-49.

https://doi.org/10.24127/ja.v3i1.148

Disas, E. P. (2017). Analisis Kebijakan Pendidikan Mengenai Pengembangan Dan Peningkatan Profesi Guru. Jurnal Penelitian Pendidikan, 17(2), 158-166. https://ejournal.upi.edu/index.php/JER/article/view/8251

Fatimah, Siti Tamuri, A. A. H. (2010). Persepsi Guru Terhadap Penggunaan Bahan Bantu Mengajar Berasaskan Teknologi Multimedia dalam Pengajaran j-QAF. Journal of Islamic and Arabic Education, 2(2), 53-64.

http://journalarticle.ukm.my/783/

Fernandes, M., \& Sturm, R. (2010). Facility Provision in Elementary Schools: Correlates with Physical Education, Recess, and Obesity. Preventive Medicine, 50, S30-S35. https://doi.org/10.1016/j.ypmed.2009.09.022

Gumanti, A., Yudiar, \& Syahruddin. (2016). Metode Penelitian Pendidikan. Jakarta: Mitra Wacana Merdeka.

Haruthaitlianasan, T. (2020). Effects of School Policies Toward Competitive and Collaborative Approaches on Teachers' Instruction and Students' Learning in Schools in Southern Thailand. Kasetsart Journal of Social Sciences, 41 (2), 262268.

https://doi.org/10.1016/j.kjss.2018.07.022

Herliandry, L. D., Nurhasanah, Suban, M. E., \& Heru, K. (2020). Pembelajaran Pada 
Masa Pandemi Covid-19. Jurnal Teknologi Pendidikan, 22(1), 65-70.

https://doi.org/https://doi.org/10. 21009/jtp.v22i1.15286

Novayani, I. (2018). Pembelajaran Pendidikan Agama Islam (Pai) Berbasis Multikultural. Tadrib: Jurnal Pendidikan Agama Islam, 3(2), 235-250. https://doi.org/10.19109/Tadrib.v3i2.1795

Nurkholis. (2020). Dampak Pandemi Novel-Corona Virus Disiase ( Covid-19) Terhadap Psikologi Dan Pendidikan Serta Kebijakan Pemerintah. Jurnal PGSD, 6(1), 39-49. https://e-journal.umc.ac.id/index.php/JPS

Pingge, H. D. (2016). Faktor Yang Mempengaruhi Hasil Belajar Siswa Sekolah Dasar Di Kecamatan Kota Tambolaka. Jurnal Prima Edukasia, 4(2), 134-147. https://doi.org/10.21831/jpe.v4i2.6458

Pujilestari, Y. (2020). Dampak Positif Pembelajaran Online Dalam Sistem Pendidikan Indonesia Pasca Pandemi Covid-19. Adalah: Buletin Hukum Dan Keadilan, 4(1), 49-56.

https://doi.org/10.15408/adalah.v4i1.15394

Rochidin, W. (2011). Pembelajaran Pendidikan Agama Islam Dalam Mewarnai Kualitas Pendidikan Di Sekolah. Jurnal Kependidikan: Penelitian Inovasi Pembelajaran, 41(2), 144-150. https://doi.org/10.21831/jk.v41i2.1928

Rofi'ah, S. dalam S. (2017). Persepsi Pendidik PAI Tentang Pembelajaran Multikultural Di Madrasah Ibtidaiyah Berbasis Pesantren. Jurnal Muallimuna, 2(2), 28-40. https://ojs.uniska-bjm.ac.id/index.php/jurnalmuallimuna/article/view/766

Solichin, M. (2015). Implementasi Kebijakan Pendidikan Dan Peran Birokrasi. Jurnal Studi Islam, 6(2), 148-178. https://doi.org/1978-306X

Stein, R. A. (2020). COVID 19 and Rationally Layered Social Distancing. International Journal of Clinical Practice, 74(7), e13501, 1-3. https://doi.org/10.1111/ijcp.13501

Sugiyono. (2016). Metode Penelitian Pendidikan:(Pendekatan Kuantitatif, Kualitatif dan $R \& D)$. Bandung: Alfabeta.

Sutrisno, V. L. P., \& Siswanto, B. T. (2016). Faktor-Faktor Yang Mempengaruhi Hasil Belajar Siswa Pada Pembelajaran Praktik Kelistrikan Otomotif SMK Di Kota Yogyakarta. Jurnal Pendidikan Vokasi, 6(1), 111-120. https://doi.org/10.21831/jpv.v6i1.8118

Ulfa, M., Stang, Tahir, A. M., Mallongi, A., \& Rachmat, M. (2020). Effect of Education Media on Improvement Visual Acetate Acid Inspection at Sudiang Community Health Center. Enfermeria Clinica, 30(4), 439-443. https://doi.org/10.1016/j.enfcli.2019.10.118

Vu, C. T., Hoang, A. D., Than, V. Q., Nguyen, M. T., Dinh, V. H., Le, Q. A. T., ... Nguyen, Y. C. (2020). Dataset of Vietnamese Teachers' Perspectives and Perceived Support During The COVID-19 Pandemic. Data in Brief, 31, 105788. https://doi.org/10.1016/j.dib.2020.105788

Walgito, B. (2010). Pengantar Psikologi Sosial. Yogyakarta: Andi Offset. 